\title{
MASTERING
}

\section{ITALIAN 2}

Italian Life and Language 


\section{MACMILLAN MASTER SERIES}

Astronomy

Australian History

Background to Business

Banking

Basic English Law

Basic Management

Biology

British Politics

Business Communication

Business Law

Business Microcomputing

Catering Science

Chemistry

COBOL Programming

Commerce

Computer Programming

Computers

Data Processing

Economic and Social History

Economics

Electrical Engineering

Electronics

English Grammar

English Language

English Literature

Financial Accounting

French

French 2
German

German 2

Hairdressing

Italian

Italian 2

Japanese

Keyboarding

Marketing

Mathematics

Modern British History

Modern European History

Modern World History

Nutrition

Office Practice

Pascal Programming

Physics

Practical Writing

Principles of Accounts

Restaurant Service

Social Welfare

Sociology

Spanish

Spanish 2

Spreadsheets

Statistics

Statistics with your Microcomputer

Study Skills

Typewriting Skills

Word Processing 


\section{MASTERING}

\section{ITALIAN 2}

\section{Italian Life and Language}

\section{ROBERT C. POWELL \\ and}

ROBERTA TOZER

\section{Editorial Consultant B E T T Y P A R R}

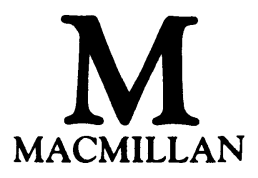


(C) Robert C. Powell and Roberta Tozer 1989

All rights reserved. No reproduction, copy or transmission of this publication may be made without written permission.

No paragraph of this publication may be reproduced, copied or transmitted save with written permission or in accordance with the provisions of the Copyright Act 1956 (as amended), or under the terms of any licence permitting limited copying issued by the Copyright Licensing Agency, 33-4 Alfred Place, London WC1E 7DP.

Any person who does any unauthorised act in relation to this publication may be liable to criminal prosecution and civil claims for damages.

First published 1989

Published by

MACMILLAN EDUCATION LTD

Houndmills, Basingstoke, Hampshire RG21 2XS

and London

Companies and representatives

throughout the world

\section{British Library Cataloguing in Publication Data}

Powell, Robert C.

Mastering Italian 2: Italian life and

language.-(Macmillan master series).

1. Italian language-Questions \& answers

I. Title II. Tozer, Roberta III. Parr,

Betty

458

ISBN 978-0-333-43574-8

ISBN 978-1-349-19843-6 (eBook)

DOI 10.1007/978-1-349-19843-6 


\section{CONTENTS}

List of figures

List of illustrations

Series editor's preface

Introduction: how to use this book

xiii

Guide to pronunciation

\section{TEACHING UNITS}

\section{L'Italia patria mia}

1.1 Per una definizione dell'Italia

Grammar: Revision of present tense; present continuous tense; adjectives: formation and use; comparisons; passive use of si

1.5 Informiamoci: L'Italia; dati geografico-politici

1.6 Conversazione: L'Italia vista dall'esterno

Grammar: Noun endings

Communicaton skills: Saying how long you have been doing something; keeping the conversation flowing

1.9 II paese più preparato per entrare nel terzo millennio?

Grammar: Noun endings

1.13 Conversazione: Nostalgia per il mio paese

1.14 Una canzone: L'Italiano

\section{L'Italia felice}

2.1 Lei ci crede che gli italiani sono felici?

Communication skills: altro che; reporting speech

Grammar: Uses of the subjunctive; the absolute superlative; the infinitive as a noun

2.5 L'Oroscopo del giorno

2.6 Conversazione: Ma tu ci credi agli oroscopi?

Communication skills: Expressing agreement

2.7 La religiosità degli italiani

Communication skills: Making comparisons; saying 'both'; saying 'both . . . and'

Grammar/Style: the position of adjectives; abstract nouns 


\section{L'Italia in vacanza}

3.1 Che tipo di vacanziero sei?

Grammar: Use of ne; use of si; uses of da

Communication skills: Getting someone to do something; saying that you are trying to do something

3.4 Agenzie di viaggi

Grammar: Formation and use of adverbs; relative pronouns; demonstrative pronouns

3.8 Informiamoci: Viaggiando in Italia Grammar: Further uses of the subjunctive

3.11 Conversazione: Una vacanza avventurosa Communication skills: Saying that you enjoyed something; saying what happened to you

3.13 Informiamoci: Vivere bene in vacanza

\section{L'Italia a tavola}

$4.1 \quad$ L'elogio dei maccheroni? $\quad 86$

4.4 Informiamoci: Deciphering the menu 91

4.6 Conversazione: La cucina italiana in Inghilterra 93 Communication skills: Asking how something is done; saying how much time something takes

4.7 Mangiare natura

Grammar: Passive voice; moods of the verb; uses of the future tense

Communication skills: Expressions of quantity; talking about when things occur

4.11 Conversazione: Ottimi cuochi in famiglia

Communication skills: Asking questions

\section{L'Italia in famiglia}

5.1 Conversazione: La domenica in famiglia 111

Grammar: Further uses of $s i$

5.4 II padre italiano

Communication skills: Saying that you have to do something; saying that you are capable of doing something; more expressions of time; expressing annoyance

Grammar: Imperfect tense; past definite tense; use of gerund; position of pronouns with infinitives and gerunds; another use of $d a$

5.8 Cronaca di un inferno familiare

Communication skills: Saying that something matters; saying what is needed; saying 'It has nothing to do 
with'; expressing the notion of 'expecting'

Grammar: Omission of the indefinite article; passato prossimo; conditional sentences; more uses of the subjunctive

5.12 Conversazione: I bambini coccolati

Grammar: More conditional sentences; using riuscire

\section{L'Italia al volante}

143

6.1 Corri, italiano, corri ... .

Grammar: Irregular superlatives; using venire; uses of the infinitive

6.5 Informiamoci: Sulle autostrade

6.6 La finanza deve ancora scoprire l'autostrada

Communication skills: Talking about money

6.8 Conversazione: Girare a Napoli

6.10 La civiltà dell'auto ha le gomme a terra?

Grammar: Some further uses of the infinitive

Communication Skills: Developing a discussion

\section{L'Italia giovane}

7.1 Quanto siamo diversi

Communication skills: Saying that something is irrelevant; saying you are upset; saying you could not care less; saying what impressed you; presenting both sides of an argument; asking for an opinion

Grammar: Verbs with a dependent infinitive; uses of appena; further uses of the subjunctive

7.5 Conversazione: Ricordi di scuola

Grammar: Passato prossimo and imperfetto

7.7 Informiamoci: Le scuole italiane

7.9 Tra padre e figlia

Communication skills: Saying 'from time to time'; talking about differences of opinion; saying what you ought to do; saying you are wrong; saying what you feel like doing Grammar: Negative expressions; further uses of the subjunctive; suffixes; using magari

7.13 Conversazione: II tempo libero e gli amici 
Grammar: Direct and indirect object pronouns; indefinite pronouns and adjectives; come se; translating 'such'

Communication skills: Using già; saying 'not to mention'

8.6 Numero sbagliato

Grammar: Pronoun combinations; future of irregular verbs; using badare

8.9 II telefono: un collaboratore sempre pronto 211

8.10 Informiamoci: Radio e televisione 213 Grammar: II passato remoto

8.13 Radio Centrale

8.14 Informiamoci: La stampa 219

9 L'Italia: lingua e cultura

\section{La lingua italiana}

9.1 L'Italiano oggi

Grammar: More verbs with dependent infinitives

9.5 Corsi di lingua e cultura in Italia

Communication skills: Formal letter-writing

9.6 A case of 'Fritalinglese'?

9.7 II Nuovo Galateo

Communication skills: When to use tu, lei and voi; asking for the meaning of things; making suggestions

\section{La cultura italiana}

9.11 Informiamoci: II cinema italiano 237

9.12 L'opera

Grammar: More conditional sentences; the perfect conditional tense; more uses of the subjunctive; special uses of the future and future perfect tenses

10 La letteratura italiana

10.1 Nota dell'autore - Ignazio Silone 252

10.2 Alla porta dell'Inferno - Dante 255

10.3 Il giovane Dante e la politica - Mario Tobino 256

10.4 Fra Cristoforo arriva al palazzo di Don Rodrigo 258 - Manzoni

10.5 Prologo a la noia - Alberto Moravia 
10.6 Due poesie di Giuseppe Ungaretti

10.7 Una poesia di Eugenio Montale 264

10.8 II ritorno in Sicilia - Elio Vittorini 267

10.9 II rifiuto - Italo Calvino 269

10.10 Un giallo del Medioevo - Umberto Eco 271

\section{REFERENCE MATERIAL}

Key to the exercises

Grammar section

Grammar section index

Bibliography and useful addresses 


\section{LIST OF FIGURES}

1.1 Italy today: main towns and regions

1.2 A comment on the Italian economy

2.1 'll Jolly'

3.1 Vivere bene in vacanza

4.1 Advert for the 'Bar-Ristorante Commercio'

4.2 One of the problems of insisting on 'pollo ruspante'?

5.1 The Italian football pools

5.2 Between father and son

6.1 Italy's motorway network: expansion 1955-86

6.2 A Rome bus ticket

7.1 Come non detto

8.1 Italians and the mass media

8.2 Network based on root words

8.3 Telephone services

8.4 RAl advert

213

8.5 Italian periodicals and daily papers

8.6 Choosing an Italian headline

221

9.1 Tina courses

9.2 Italian cinema

9.3 The trouble with having opinions 


\section{LIST OF ILLUSTRATIONS}

1.1 A scene in winter

2.1 The parish priest

3.1 Holidays in Italy

3.2 Positano in the spring; the Amalfi coast is a popular holiday destination

4.1 Italian cooking

4.2 Shopping for Italian ingredients

5.1 An Italian Sunday

94

5.2 An Italian childhood

6.1 A busy street in Naples

6.2 Italians on the road

7.1 Going to school

165

7.2 Political Italians

8.1 The campanile

9.1 Old men at Sorrento

9.2 The theatre in Reggio Emilia where Pavarotti's career began

10.1 Eyes right in Venice 


\section{SERIES EDITOR'S PREFACE}

\section{MASTERING ITALIAN 2}

Mastering Italian 2 is intended for students working, with or without a teacher, to extend their command of spoken and written Italian and to learn more about Italy and her people. When Mastering Italian was published in 1983, it was described as 'a carefully planned introduction to the language and . . . a secure foundation for further study'. The present course is a sequel to the first, and will surely be welcomed by thousands who have studied Mastering Italian and by many others who have a good basic knowledge of the language and seek a stimulating and well organised programme to support more advanced work, with or without an examination in view.

In the first Course, the main emphasis was placed on understanding and using the spoken language, although reading and writing were given due attention. In Mastering Italian 2, the ready comprehension and effective use of the written language are important objectives, though listening and responding to spoken Italian are also vital elements. A glance at the table of contents will give a hint of many individual features, though it will not reveal the lively teaching and sensitive understanding that characterise the Course. A selection of authentic passages from contemporary sources gives an insight into aspects of life in present-day Italy. Some of these form the basis for recorded conversations, which provide a further source of information and opinion, and an excellent demonstration of the language as spoken by well-educated Italians. The last chapter contains a small anthology of literary extracts, from Dante to the present day; it is hoped that the student may be stimulated by this glimpse of Italian literature to embark on further reading in this rich field.

The authors' most helpful and informative introduction gives an account of the contents of the book and its accompanying cassette, and suggests ways of using them effectively. Helpful notes on each extract should assist the student to develop a measure of linguistic 


\section{PREFACE}

independence and a sense of style. The grammatical explanations which follow the chosen passages ensure that grammar is learnt in the context of familiar material, not in theoretical isolation. A comprehensive and comprehensible Grammar Section in the Appendix of reference material gives fuller information in an accessible form. Exercises carefully planned to provide practice in all the language-skills are accompanied by a key, placed in the Appendix, which should instil confidence and facilitate self-assessment.

To work with this Course is to embark on an enjoyable voyage of discovery which should lead to increased mastery of the Italian language and a deeper understanding of Italy and her people.

BETTY PARR

Editorial Consultant 


\section{INTRODUCTION}

\section{HOW TO USE THIS BOOK}

\section{THE STUDY MATERIAL}

Mastering Italian 2 is intended for people who already have some basic knowledge of Italian and who wish to extend their understanding of the language. This second-stage book includes a range of spontaneous conversations recorded with Italian native speakers from several different parts of the country. It also offers a wide variety of authentic reading material taken from newspapers, magazines, information brochures and literature. The range of registers of the various texts, together with the topics developed in the ten chapters, provide fascinating insights into the language, society and culture of contemporary Italy.

In selecting the material for study, we have borne in mind the needs of several types of language learner.

$\star$ Adult learners working independently who want a varied diet of authentic reading and listening material, helpful notes of clarification and a guided programme of self-checking exercises to assess their own performance.

$\star$ Students attending classes on second- or third-stage courses in adult education centres or institutions of further education. Mastering Italian 2 will be a useful addition to the list of course books available to the teacher. It could also be a useful supplement for students' work at home.

* Students preparing intermediate or advanced-level certificates set by the various regional and national examination boards.

* Students who have completed an intensive beginners' course in Italian at school, polytechnic, university or in Italy itself, and who need to develop further their reading, listening and writing skills and knowledge of structure and vocabulary. 
* Business people whose knowledge of spoken Italian may be quite extensive but who have had no formal learning experience. Mastering Italian 2 will develop their reading and writing skills and explain some of the more formal aspects of language usage.

^ People of Italian origin whose mother-tongue may be a dialect form but who now wish to formalise their understanding of the national language. This book offers a coherent programme of study to enable them to develop their reading and writing skills in standard Italian.

\section{LINGUISTIC GOALS}

\section{Reading Skills}

All of the Italian language presented for study and enjoyment in this book is authentic - that is to say, it has been published in its original form, if not always in its original format. It is inevitable, therefore, that some of the passages may appear rather difficult on first reading. With practice, however, and developing confidence gained through an increasing vocabulary, you should find things becoming much easier. You should not be put off if you do not understand every single word immediately. The tasks set on each text will take you through various stages, from gist comprehension - which involves gaining a grasp of the general ideas - through more detailed understanding of the arguments presented and appreciation of the style and purpose of the writing. For the vocabulary and idiom of the texts to become part of your own 'repertoire', you will need to read and re-read each passage and conversation several times. Reading aloud can help speed up the process of assimilating a new language. By and large, material has been chosen from publications that are widely available outside Italy, thus encouraging you to continue your discovery of the language and society of that country.

\section{Listening Skills}

The cassette which accompanies this book contains recordings of the Conversazioni, examples from the Pronunciation Guide, answers from some of the Exercises and readings of some of the literary extracts. There are also some items from an Italian local radio station. All items on the cassette are marked in the text with the cassette symbol As well as using the cassette as an essential tool during formal study time, why not listen on your way to work, or while you peel the potatoes? It is worth talking along with the native speakers, reproducing their pronunciation and intonation. Some 
people claim to learn a great deal by listening to the foreign language cassette last thing at night, just before dropping off to sleep!

\section{Communication Skills}

In addition to the notes clarifying the expressions contained within each passage, idiomatic phrases of spoken Italian have been singled out for special attention. These are primarily intended to help the traveller to Italy cope with typical, everyday situations. Some of the exercises are designed especially to practise oral skills and a number of these exercises have been recorded on the cassette.

\section{Grammatical Skills}

An understanding of the underlying structure of a language is essential if you are to develop fluency and accuracy in all the four language skills of listening, speaking, reading and writing. Each chapter contains sections entitled Explanations which, as well as providing vocabulary lists to assist comprehension, include grammatical details based on examples taken from the texts. Studying grammar in context is the best way to increase your ability to manipulate language. You should always study the relevant parts of the Grammar Section at the end of the book to supplement the notes in the chapters. This summarises the main grammar points of the book and provides further examples.

\section{EXERCISES}

Exercises are set after each passage or conversation to help you check your understanding of the ideas and your linguistic competence. We have tried to make the exercises as varied and as interesting as possible. Some involve role-play and test oral skills, while others focus on written skills such as summarising, translation or letterwriting. You should check your progress regularly by referring to the Key to the Exercises, also to be found at the back of the book - after attempting the exercises, of course!

\section{TYPEFACES}

Throughout this book, words in Italian are printed in a different typeface from English words. This approach, it is hoped, will avoid any confusion, particularly in the Explanations and Exercises. Most Italian words have the stress on the penultimate syllable; words which do not follow this pattern have the stressed syllable shown in italics in 
the Select Vocabulary lists. (See also the discussion of l'enfasi (stress) on p. $x x v$ below.)

\section{INFORMATION ABOUT ITALY}

There are several passages headed Informiamoci which are designed to increase your awareness and appreciation of modern Italian society. Some offer practical advice to the traveller or holiday-maker. Topics such as geography, politics, health, cinema and the mass media are also included.

\section{REFERENCE MATERIAL}

No single text book can cover all aspects of the foreign language and culture. The serious student of Italian will need a good dictionary and the support of a fuller description of the language. A list of suggested titles appears at the back of the book, together with some useful addresses for obtaining more information about Italy, courses in Italian, and Italian life and culture.

\section{PLANNING TO USE THE BOOK AND CASSETTE}

In the first two or three chapters of the book, some of the basic elements of Italian have been isolated for special attention-e.g. noun and adjective formation and use of tenses. Beyond this, however, there is no attempt to create an artificial progression from 'simple' to 'complex' language. What some language learners find difficult, others may find easy. You are therefore free to choose the sequence in which the chapters are to be read and studied. You may follow the chronological order, taking each passage in turn and completing the work set; you may decide to concentrate on listening first and spend more time with the conversations on the cassette before working on your reading and writing skills. Having looked at the themes of the chapters in the Contents, you may select one that particularly appeals and study those units of work first. Whichever route you take, we hope you will find the topics interesting and the tasks challenging and rewarding. Buon Lavoro! 


\section{GUIDE TO PRONUNCIATION}

四

The first volume of Mastering Italian included a very brief guide to the pronunciation of the Italian language. This section takes the student of Italian as a foreign language several steps further along the road to developing a perfect accent: Italian is not really a difficult language to pronounce well. It is sometimes called a 'phonetic' language; this means simply that what you see written on the page is pronounced more or less as it is written, with every single part of each word having its importance in the sentence. In order to make the most of this section, you should read it in conjunction with the cassette. The examples have been recorded for you. Listen to them carefully and copy the native speakers. There are many regional accents in Italian but the pronunciation of the national language, as opposed to the regional dialects, remains fairly constant throughout Italy.

\section{L'ALFABETO (the alphabet)}

If you need to give your name on the telephone to an Italian who does not understand English, it is as well to adopt the system of providing a place name for each letter of the alphabet. A list of the towns used in this way is given below.

If your name was Powell, for example, you would spell it out thus:

P come Padova - O come Otranto - W come Washington - E come Empoli - L come Livorno - L come Livorno 


\section{PRONUNCIATION}

There is no Italian town beginning with W. Similarly, if your name contained $\mathrm{H}$ or $\mathrm{Q}$, you would say:

$\mathrm{H}$ (acca) come Hotel, $\mathrm{Q}$ come quaranta

$\begin{array}{llll}\text { A (a) } & \text { Ancona } & \text { O (o) } & \text { Otranto } \\ \text { B (bi) } & \text { Bologna (or Bari) } & \text { P (pi) } & \text { Padova (or } \\ \text { C (ci) } & \text { Como } & & \text { Parma) } \\ \text { d (di) } & \text { Domodossola } & \text { O (cu) } & \text { quaranta } \\ \text { e (e) } & \text { Empoli } & \text { R (erre) } & \text { Roma } \\ \text { F (effe) } & \text { Forlì } & \text { S (esse) } & \text { Savona } \\ \text { G (gi) } & \text { Genova } & \text { T (ti) } & \text { Torino } \\ \text { H (acca) } & \text { Hotel } & \text { U (u) } & \text { Udine } \\ \text { I (i) } & \text { Imola } & \text { V (vi) } & \text { Venezia (or } \\ \text { L (elle) } & \text { Livorno } & & \text { Vicenza) } \\ \text { M (emme) } & \text { Milano } & \text { W (vi doppia) } & \text { Washington } \\ \text { N (enne) } & \text { Napoli } & \text { Z (zeta) } & \text { Zara }\end{array}$

(note that we have marked where the stress falls when it is not on the penultimate syllable - Domodossola)

The letters $\mathrm{J}, \mathrm{K}, \mathrm{X}$ and $\mathrm{Y}$ are not really part of the Italian alphabet, but are referred to in the following way:

$\mathrm{J}=\mathrm{i}$ lunga

$\mathrm{K}=$ cappa

$\mathrm{X}=$ ics

$Y=$ ipsilon

\section{LE VOCALI (the vowels)}

1. Italian vowels are mostly 'pure' sounds. The voice should not slur over the sounds as often happens in English. Any comparison between the two is only a rough approximation, as the cassette will indicate.

English word

$$
\begin{array}{ll}
a & \text { bar } \\
e & \text { Fred } \\
i & \text { chips } \\
\text { o } & \text { port } \\
u & \text { cube }
\end{array}
$$

\section{Italian word}

un bar
freddo
cipria
porto
cubo

un bar freddo porto cubo 
Note that in some words the vowel $o$ is pronounced with an 'open' sound, as in the English word 'pot':

ottimo, costo, ho

In others, it has a more 'closed' or narrow sound, as in the English word 'closed':

molto, dopo

Similarly, the vowel $e$ has two kinds of sound: an 'open' $e$ :

espresso

and a 'closed' version:

nero, sera, meno, etc.

These vowel sounds do vary slightly from region to region.

The vowel $i$ placed between $c$ or $g$ and $a, o, u$, is hardly pronounced at all, but changes the sound of the consonant from a hard, guttural one to a soft, palatal one:

chocolate $=$ cioccolata, everyone $=$ ciascuno,

John $=$ Giovanni, jacket $=$ giacca

2. Diphthongs (i dittonghi) usually occur when a hard vowel (a,e or 0 ) combines with a soft one ( $i$ and $u)$. In these cases, the stress always falls on the hard one:

fiore, fianco, pieno, riunione, poi, noi, paio, laico, dieta, chiesa, etc.

When two soft vowels combine, the stress falls on the second one:

piuma, Luisa

Learn the exceptions as you come across them in the recordings and in talking to Italians:

poema, platea, qualsiasi 


\section{PRONUNCIATION}

\section{LE CONSONANTI (the consonants)}

1. $\quad c$ and $g$ in front of the vowels $e$ and $i$ have a soft sound, similar to that found in the English words 'chair', 'cheer', 'jug', 'gin', 'gem':

centocinquanta, gengiva

In some regions of Italy you will hear the soft $c$ pronounced even 'softer', bordering on the English 'sh' sound.

Before the vowels $a, o, u, c$ and $g$ are hard, guttural sounds, like the English $\mathrm{c}, \mathrm{k}$ and $\mathrm{g}$ :

cocoa $=$ cacao, cuddle $=$ coccolare, gargle $=$ gargarismo, government $=$ governo, etc.

2. $c h$ and $g h$ are found only in front of $e$ and $i$. Think of the $h$ making the $c$ and $g$ hard:

chiesa, chilo, perché, ghiaccio, ghisa, ghetto

3. $g$ followed by $I$ and the vowels $a, e, o, u$ has a hard, guttural sound:

globale, Gloria, inglese, etc.

But $g /$ before the vowel $i$ is usually a soft palatal sound, like -liin 'million':

foglio, figlia, gli

In a few instances, however, it retains its hard quality:

anglicano, negligenza, glissando, glicerina

4. The sound of $g$ followed by $\boldsymbol{n}$ and any of the vowels is always soft, similar to the English -ni- in 'onion', or ne- in 'newt':

gnocchi, agnello, bagno, Ignazio

5. $h$ is always silent, for example in parts of the verb avere:

ho, hai, ha, hanno 
6. qu followed by another vowel is pronounced as in the English words 'qualm', 'quest', 'quick':

quaderno, quercia, quindi, quotidiano

7. $r$ is 'rolled'. To achieve this sound, the tip of the tongue has to flick back, curling towards the roof of the mouth. Try, literally, getting your tongue around this sentence:

II treno numero trentatrè è arrivato da Trieste con tre ore di ritardo

8. s has two sounds:

(a) Unvoiced, like the English 'soap', in several instances.

When it is the first letter of a word and followed by a vowel:

salute, senza, sicurezza, solo, sugo

When it is doubled:

rissa, rosso, influsso

When it is followed by $c, f, p, q, t$ :

scacco, sfondo, speciale, studente

(b) Voiced, like the English 'pose'.

When it is at the beginning of a word and followed by the consonants $b, d, g, l, m, n, r, v$ :

sbaglio, sdraio, sgradevole, smarrire, snello, sviluppo

and generally when it is within a word:

esercizio, quasi

9. $s c$ has two pronunciations.

(a) Similar to the English 'shoot' in front of $e$ and $i$ :

sci, sciopero, scemo, lascerò 
(b) Similar to the English 'scheme' in front of a, o, u:

scatola, scoglio, scusi

10. $s g$ also has two pronunciations (as in $\mathbf{1}$ above), namely a palatal soft sound before $e$ and $i$ :

sgelare

and a guttural, hard sound before $a, o, u$ :

sgabello, sgonfiato, sguardo

But $s c$ and $s g$ are followed by $h$ only in some instances, and only in front of $e$ and $i$ to give a guttural, hard sound:

schema, schiaffo, schiena, pesche, fischio, sghembo, funghi, aghi

11. $z$ has two pronunciations.

(a) Unvoiced, similar to the sound 'ts' in the English word 'bets':

zampa, zeppo, zero, zucchino, forza

(b) Voiced, similar to the sound ' $\mathrm{dz}$ ' in the English word 'lads': zona, zigomo, zanzara

12. Double consonants must be pronounced strongly, since some words have quite different meanings which depend solely on a single or double consonant (cf. English pen-knife):

pena - penna
sono - sonno
poro - porro
Papa - pappa

Double consonants require the speaker to pause fractionally longer on the sounds. Notice the difference between the following: 
ha fatto - affatto

palo - Rapallo

la porta - rapporto

il rame - rammarico

\section{L'ENFASI (stress)}

Italian words may be divided into four groups according to where the stress falls. As we have seen, some words are stressed on the last syllable. The largest group of Italian words, however, are stressed on the penultimate (next to last) syllable:

curva, maniglia, adagio, informale, gradualmente, industrializzazione

Note the stress points in a typical Italian sentence:

Trovo l'italiano molto interessante

A number of words have the stress falling on the antepenultimate (third last) syllable:

facile, papavero, mutabile, popolo, catalogo, caotico, abito, pubblico, palcoscenico, femmina, portacenere, medico, drammatico, giocattolo, etc.

Listen out for these in speech and in recordings, making a note each time you hear a new example.

There are a number of instances where this pattern is regularly followed:

(a) The absolute superlative ending -issimo:

bellissimo, interessantissimo, difficilissimo

(b) Verb endings such as the $3 r d$ person plural present tense (indicative and subjunctive):

possono, trovano, facciano, ammettono

(c) Some infinitive forms:

accendere, trascorrere, rispondere 
(d) Verb forms where pronouns are tagged on to the end, for example imperatives:

fermatevi, mandatelo, scrivetemi

and participles:

finitolo, essendoci, mangiandone

A handful of words, usually verb forms, have the stress on the fourth last syllable:

partecipano, illuminano, si accomodino

This will also occur if two pronouns are added to the imperative or participle:

mandategliene, dettomelo

In other words, the stress matches that of the original form without the addition of a pronoun.

Words having an 'unusual stress' - i.e., other than on the penultimate syllable - will be identified in the Select Vocabulary lists with the stressed syllable in bold type:

pianerottolo - landing

Many words ending in -io and -ia, etc. have the stress on the $i$ of the ending (i.e., the penultimate syllable):

farmacia, mormorio

But there is no hard and fast rule about this. Some words ending in -io and -ia have their stress on the preceding syllable:

ordinario, storia

All words with these kinds of endings will have their stress marked in the Select Vocabulary lists, but you should make a note of others as they occur in the recorded material. 


\section{L'INTONAZIONE (intonation)}

Italian is frequently referred to as a musical language. The purity of the vowel sounds and the interplay of soft and hard consonants certainly add to the beauty of the spoken language. But there is also a lyrical quality to be found in the rise and fall of the voice pitch. Not all Italians seem to sing as they speak, but the overriding impression one gains listening to people from various parts of Italy is that the range of tonality and the differences of pitch are greater than in some other languages.

As you listen to the cassette you should try to echo the way Italian mother-tongue speakers string together their ideas. Notice particularly where the voice rises and falls in the sentence. One way to help develop an ear for intonation is to draw lines above the words in a sentence, rather like a set of musical notes. Below is an example, showing how varied the pitch can be, even when the subject matter is quite mundane - an extract from 'A day in the life of . . . Roberta.'

\section{$\widetilde{\text { Dunque }}, \widetilde{\text { mi sveglio alla mattina }}, \widetilde{\text { piuttosto presto, }} \overline{\text { verso le sei e tre }}$} quarti, le sette meno dieci. Faccio colazione che non consiste di molto perché come tutti gli italiani adoro soprattutto î́ mio caffè.
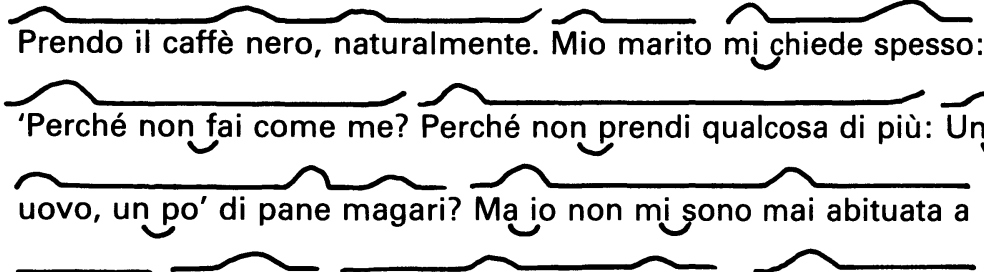

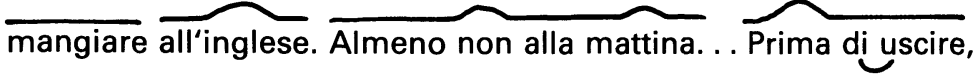
metto in ordine qualche cosa nella casa e poi mi avvio al lavoro verso le otto e mezzo. 


\section{ACKNOWLEDGEMENTS}

I would like to register my sincere thanks to my co-author and language consultant Roberta Tozer for her linguistic expertise and astute observations during the writing of this book. We are also grateful to Laura Gallone-Scarth, Pippo Cirino, Ernesto Macaro and Sandro Marchetti for their lively contributions during the recording sessions. Thanks are also due to the series editor, Betty Parr, for her encouragement and friendly advice. Most of all, I should like to thank my wife, Margaret, for her constant support and my children Daniel, Benjamin and Rebecca for being so patient while Dad was 'busy on the book'.

The publication of this book which draws so heavily on authentic materials would not have been possible without the cooperation of several organisations and publishers who have kindly given permission for the use of copyright material. Thanks are due to the following publishers:

Arnoldo Mondadori, Einaudi, Fabbri-Bompiani, Mursia, Rizzoli.

To the directors of the following newspapers and magazines:

L'Educatore Sanitario, Epoca, L'Espresso, Il Messaggero di Sant'Antonio, Mondo Economico, Panorama, La Repubblica, La Stampa.

To Marisa and Romano Denti, Co-Directors of Radio Centrale.

To Anna Laura Lepschy and John Parr.

To Signora Darina Silone, widow of Ignazio Silone.

To ACI Automobile Club d'Italia.

To SIP Società Italiana per l'Esercizio delle Telecomunicazioni. 
To TINA Teaching Italian by New Approaches.

To Edizioni Curci Srl.

To the Decca Record Company for extracts from 'Che gelida manina' from La Bohème by Puccini sung by Luciano Pavarotti with the Berlin Philharmonic Orchestra conducted by Herbert von Karajan. Cat. No. SXL 6649.

To Camera Press for the photographs in Chapters 1 and 8.

Every effort has been made to trace all the copyright-holders but if any have been inadvertently overlooked, the publishers will be pleased to make the necessary arrangements at the earliest opportunity. 